\title{
Further connections between the benthic marine algal floras of the northern Arabian Sea and Japan
}

\author{
Michael J. Wynne
}

Department of Biology and Herbarium, University of Michigan, Ann Arbor, Michigan 48109, USA

\section{SUMMARY \\ Identifications made on some recent collections of benthic marine algae from the Sultanate of Oman, northern Arabian Sea, have revealed several new records for this region. A total of eight species, representing five species of Rhodophyceae, two species of Phaeophyceae, and a single species each of Chlorophyceae, are newly reported for Oman. Of particular interest is the fact that these species represent new records for the Indian Ocean, some of which had previously been known from Japan and environs.}

Key words: Arabian Sea, biogeography Japanese flora, marine algae, Omani flora.

\section{INTRODUCTION}

In an early paper on the marine algae of the northern Arabian Sea, Børgesen (1934) pointed out the high incidence of shared species with the benthic marine algal flora of Japan. After deducting 23 endemic species of the total of 137 species then known from the northern Arabian Sea, Børgesen observed that 55 species were in common with Japan, or $48 \%$. The marine algal flora of the northern Arabian Sea is still relatively poorly known in comparison with the benthic marine algal flora of Japan, which is now reasonably well known (Yoshida et al. 1995; Yoshida 1998). In recent years the southern coastline of the Arabian Peninsula has been receiving closer attention (Ormond and Banaimoon 1994; Wynne and Jupp 1998; Wynne 1999b). It is becoming apparent that the seaweed flora along this coastline, including Socotra Island, Yemen, and the Sultanate of Oman, is very diverse and a number of new taxa have recently been revealed (Wynne 1998; 1999a). The dominant ecological factor of this region is the summertime monsoon, bringing high-energy conditions along with raised nutrient levels and lowered water temperatures associated with significant upwelling, in fact, the most intensely upwelled region so far known (Currie et al. 1973). This monsoon effect on the composition of the marine algal flora extends eastward, but with a gradually diminishing impact, on the Makran coast of Iran and Pakistan (Shameel et al. 1989; Shameel and
Tanaka 1992; Hayee-Memon and Shameel 1996; Shameel et al. 1996; Sohrabipour and Rabii 1999). New taxa have also been described for the Pakistani flora (Afaq-Husain and Shameel 1991; Nizamuddin 1997, 1999; Shameel 1999). The flora of the southern coastline of the Arabian Peninsula also has floristic affinities with other regions, some taxa demonstrating interesting disjunct distributions. Earlier, Wynne (1999b) reported the occurrence of Portieria japonica (Harvey) P. C. Silva and Bryopsis maxima Okamura from Oman. The former species had previously been known from Japan (Yoshida et al. 1995), Korea (Lee and Kang 1986) and the Philippines (Silva et al. 1987), whereas the latter species had not been previously reported outside of Japan. Some additional species of marine algae have been identified that represent new records for the Omani coast, as well as constituting noteworthy connections with the Japanese benthic algal flora. These new records confirm the affinities between the benthic marine algal floras of the northern Arabian Sea and Japan as first emphasized by Børgesen (1934).

\section{MATERIALS AND METHODS}

The majority of the algal species reported in this paper were collected in late September of 1999 by personnel of Hunting Technical Services of York, UK The collection of Distromum decumbens was made in January 2000. Collectors included Emma Dodsworth, Glenn Richards, Jeremy Kemp and Lynne Barratt. A few additional collections (of Cladophora ohkuboana) cited in this paper were made in 1983 by personnel of the former Tropical Marine Research Unit (TMRU) of the University of York, UK. Specimens were gathered by various methods: from subtidal habitats using scuba, sampling during periods of low tide and by picking up drift material. Some plants were processed as herbarium specimens soon after their being collected; others were preserved in 5\% formalin/sea-water. The primary set of herbarium specimens have been deposited in the Natural History Museum of Oman $(\mathrm{ON})$, Muscat, and duplicates have been deposited in

Email:mwynne@umich.edu

Communicating editor: K. W. Nam.

Received 15 February 2000; accepted 12 June 2000. 
the Natural History Museum (BM), London, and in the University of Michigan Herbarium (MICH), Ann Arbor.

\section{RESULTS}

The following list of species of red, brown and green algae are new records for the Sultanate of Oman, on the northern Arabian Sea. All species have previously been known from Japan and in most instances had been known only from Japan.

Rhodophyceae. Corallinales: Corallinaceae. Amphiroa misakiensis Yendo 1902: p. 14, pl. I, figs 24,25; pl. VI, fig. 1 (Figs 1-4)

Specimens examined grew on a rocky promontory $500 \mathrm{~m}$ east of Mirbat Island, south-east of Mirbat, Dhofar (16 $\left.57.07^{\prime} \mathrm{N}, 54^{\circ} 44.88^{\prime} \mathrm{E}\right)$ : 28.ix.1999, leg. $E$. Dodsworth 28999-04-02; epilithic, at $12 \mathrm{~m}$ depth.

The Omani specimens are in close agreement with plants of Amphiroa misakiensis from Japan according to the description given by Segawa (1940). Thalli are 3-4 cm in extent, growing in a spreading or decumbent manner (Fig. 1), with conspicuously flattened segments and with one branch surface overtopping the others. The branching pattern is dichotomous but with frequent trichotomous or polychotomous branching (Fig. 2). Sometimes as many as six or seven branches arise from the same segment. Mature intergenicula are 3-5 (-7) mm long and 1.5-3.0 (-5.0) mm broad. The genicula appear
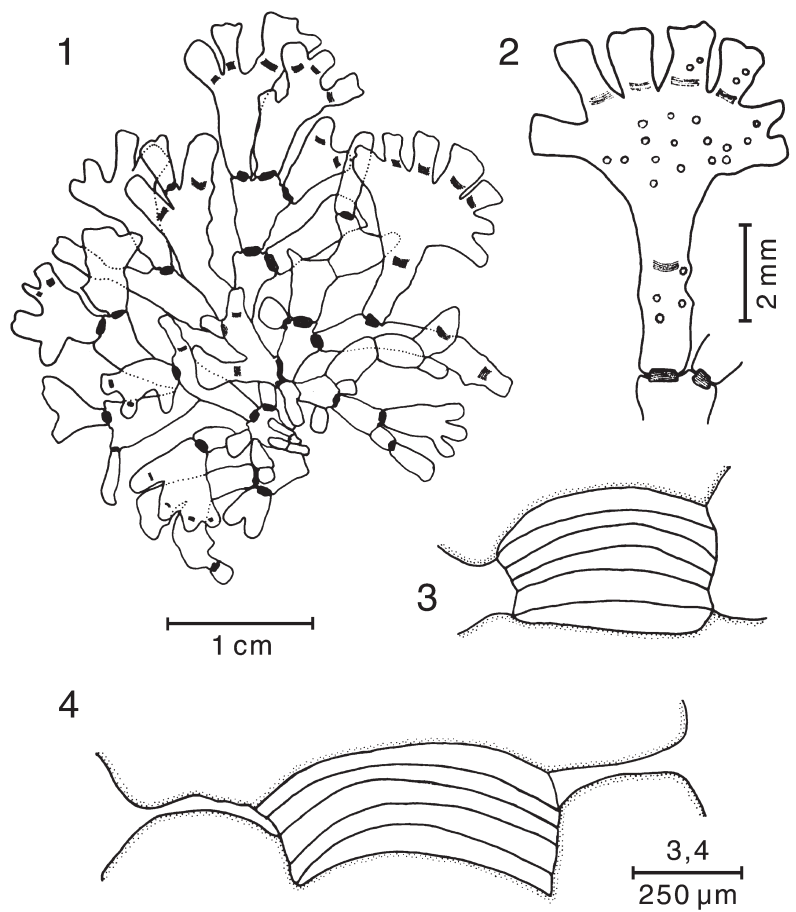

Figs 1-4. Amphiroa misakiensis. 1. Habit. 2. Example of polychotomous branching from single segment. 3,4. Schematic depictions of genicula showing tiers of cells. to consist of five to seven tiers of medullary cells (Figs 3,4). Tetrasporangial conceptacles are produced over both upper and lower surfaces of the segments. Mature tetrasporangial conceptacles measure 220$265 \mu \mathrm{m}$ in diameter.

This species was described by Yendo (1902) from a non-specified type locality in Japan. Norris and Johansen (1981) provided a detailed account of this species from Pacific Mexico. They treated Dawson's (1959) Amphiroa dimorpha var. digitiformis as a taxonomic synonym as well as Amphiroa dimorpha sensu Taylor (1945) and Dawson (1953), non Lemoine (1929), and Amphiroa pusilla sensu Dawson (1944), non Yendo (1902).

Gigartinales: Dumontiaceae. Dudresnaya japonica Okamura 1908: p. 209, pls 41,42 (Figs 5,9-16)

Specimens examined grew on a small island east of Mirbat, Dhofar ( $\left.16^{\circ} 57.00^{\prime} \mathrm{N}, 5^{\circ} 44.75^{\prime} \mathrm{E}\right)$ : 23.ix.1999, leg. Jeremy Kemp 23999-02-01, $12.5 \mathrm{~m}$ depth (female); 25.ix.1999, leg. Glenn Richards 2599902-03, at $12 \mathrm{~m}$ depth (female).

Several female-cystocarpic thalli were present in the Omani material. Spermatangia were not seen, so it was concluded that the plants were dioecious. Thalli ranged from only $4 \mathrm{~cm}$ to $30 \mathrm{~cm}$ in height (Fig. 1). Primary and secondary axes were 5-12 mm wide (when dried as herbarium specimens). Terminal cortical cells were cylindrical (Fig. 9). Carpogonial branches (Figs 10-13) consisted of usually about nine or 10 cells, but ranged from seven to 13 cells. Auxiliary cell branches were also present, the generative auxiliary cell located in an intercalary position between two darkly staining, larger nutritive auxiliary cells (Fig. 14). A thick mucilage coat over the auxiliary cell filament was not evident. Generative auxiliary cells contacted by connecting filaments were also observed (Fig. 15). Various stages of cystocarp development were present (Fig. 16). Mature cystocarps ranged from $140-220 \mu \mathrm{m}$ in diameter; the cystocarps were not distinctly cleft.

Dudresnaya japonica was described by Okamura (1908) with syntype localities of Cape Nomo (Nagasaki Prefecture), Futaye (Island Amakusa), Mie Prefecture, and Kanagawa Prefecture. The traits seen in the Omani plants agree in most respects with the account given by Robins and Kraft (1985) of this species, except for the non-cleft cystocarps and the absence of the mucilage coat around the auxiliary cell filament. Robins and Kraft depicted D. japonica as most closely related to Dudresnaya hawaiiensis $\mathrm{R}$. K. S. Lee. They distinguished this pair of species by thalli of $D$. japonica having generally terete main axes and branches, with irregularly ditrichotomous branching and being dioecious, in contrast to thalli of $D$. hawaiiensis having somewhat compressed main axes and branches, with irregular and radial branching and being monoecious (Lee 1963). 

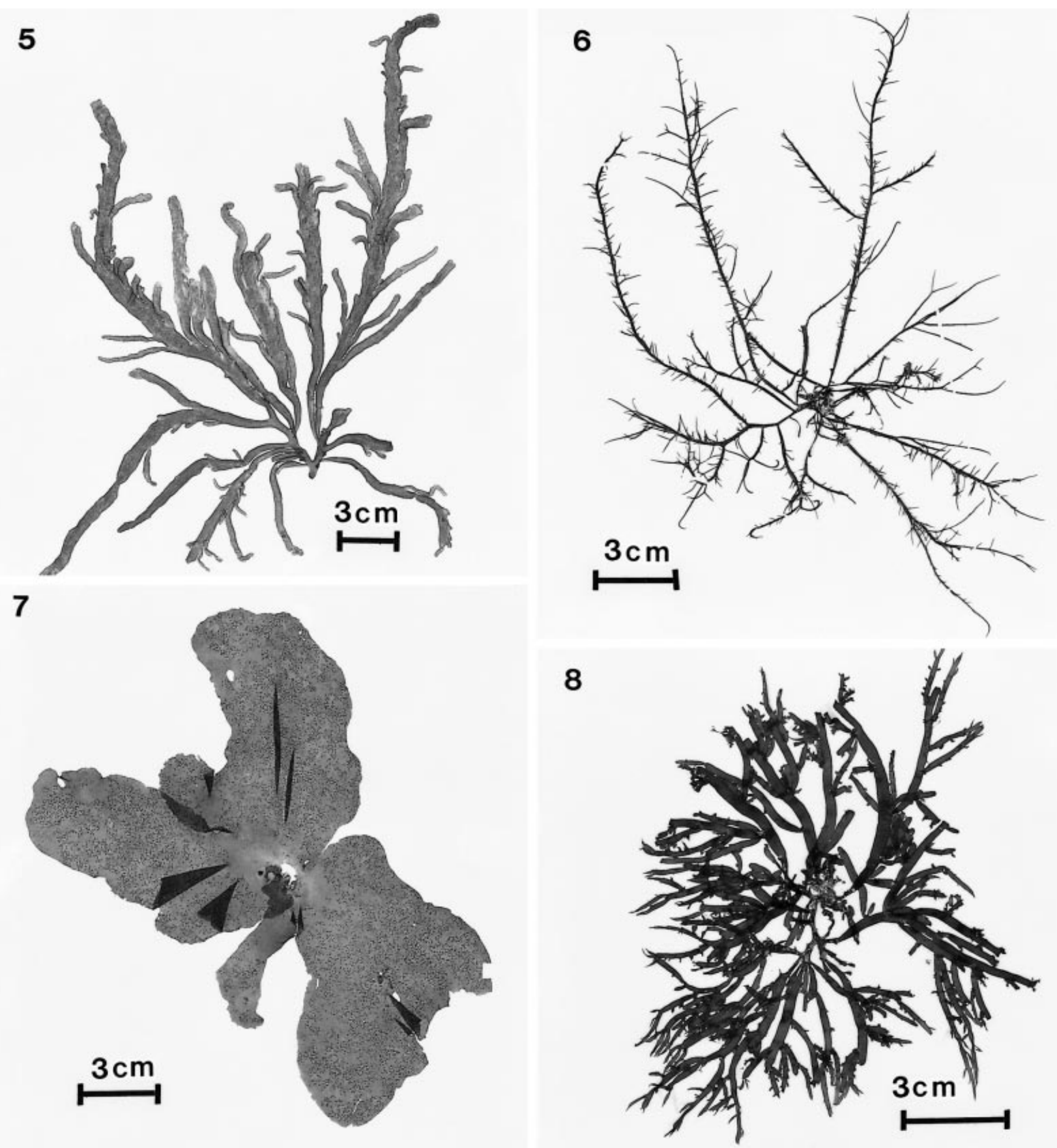

Figs 5-8. 5. Dudresnaya japonica. Habit. 6. Hypnea japonica prox. Habit. 7. Kallymenia crassiuscula. Habit. 8. Chondria crassicaulis. Habit.

Hypneaceae. Hypnea japonica T. Tanaka prox. 1941: p. 236, figs 9-10, pl. 54 (Fig 6)

Specimens examined grew on a small island east of Mirbat, Dhofar (1657.00’N ,544․ 75'E): 25.ix.1999, leg. Glenn Richards 25999-02-05; epilithic, at $12 \mathrm{~m}$ depth.

Omani plants are assigned to Hypnea japonica T. Tanaka with some reservations. This species was described originally from central Japan by Tanaka (1941) and had earlier been known as Hypnea musci- formis (Wulfen) Lamouroux (Okamura 1909), another species with hamate branches. But Tanaka distinguished his alga from that species because of its larger size and cartilaginous texture. Other differences between $H$. japonica and $H$. musciformis are that plants of the former species are more irregularly and less branched and the presence of the hook-like branches is less common (Chiang 1997). The Omani plants (Fig. 6) compare favorably to $H$. japonica in having hook-like branches and in terms of their height and thickness of the axes: $10-18 \mathrm{~cm}$ tall and $1.5-2.0 \mathrm{~mm}$ broad, whereas Tanaka described $H$. japonica to be $7-20 \mathrm{~cm}$ 
tall and 1.5-3.0 mm thick. Like H. japonica, the Omani plants have a cartilaginous or subcartilaginous texture, and produce terminal tendrils. Characteristics of the Omani plants that differ from $\mathrm{H}$. japonica include the lack of lenticular thickenings in the walls of the medullary cells, the percurrent axes and their saxicolous nature, versus the always epiphytic nature of $H$. japonica and its entangled habit lacking any percurrent axes. The Omani plants are sterile.

Another Indian Ocean species of Hypnea which forms hamate branches is Hypnea rosea Papenfuss. Papenfuss (1947) described this South African species as being closely related to $H$. japonica but distinct by its having shorter fertile branches, lacking refractive wall thickenings in the medulla, and in having its main branches tending to be percurrent. Hypnea japonica had previously been known from Japan (Yamagishi and Masuda 1997), Korea (Lee and Kang 1986), Taiwan (Chiang 1997) and China (Xia and Wang 1997).

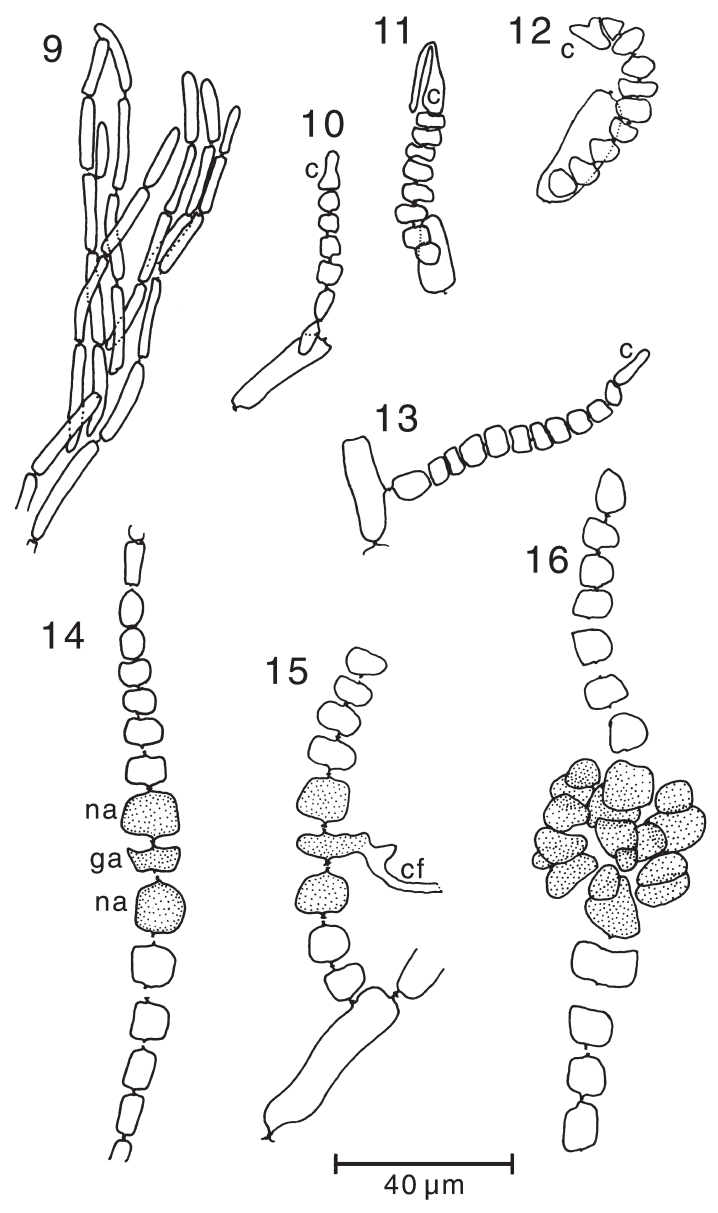

Figs 9-16. Dudresnaya japonica. 9. Cortical filaments, with cylindrical terminal cells. 10-13. Carpogonial branches. c, carpogonium. 14. Auxiliary cell branch with a generative auxiliary cell (ga) between a pair of nutritive auxiliary cells (na). 15. Generative auxiliary cell contacted by connecting filament (cf) 16. Young cystocarp.
Cryptonemiales: Kallymeniaceae.

Kallymenia crassiuscula Okamura 1934:

p. 20, 18, pl. 313, figs 1-3

(Figs 7,17-19)

Specimens examined grew north-east of Sadh Bay,

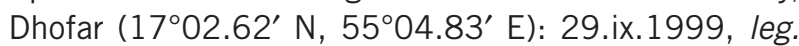
Emma Dodsworth 29999-05-05 (cystocarpic).

With a type locality of Mie Prefecture, Japan, this species was described by Okamura (1934) as having thickish, membranaceous blades with a short stem arising from a scutate disc. Blades were said to be mostly without lobes, yet often split. Okamura described the cortical layer as consisting of five to six cell layers, which gradually become smaller toward the surface, but with inner larger roundish cells. Slender medullary filaments densely traversed the central area of the frond, and dot-like cystocarps were densely scattered over the surface of the frond except the lower portion. The thallus was reported to measure $460 \mu \mathrm{m}$ in thickness with cortical layer 150-160 $\mu \mathrm{m}$ in thickness. This species has also been described by Segawa (1960) and Chihara (1975). The Omani specimens generally agreed with Okamura's account of this species. They are up to $23 \mathrm{~cm}$ tall and $9-15 \mathrm{~cm}$ wide, moderately to deeply lobed (Fig. 7). The blades lack any stem-like

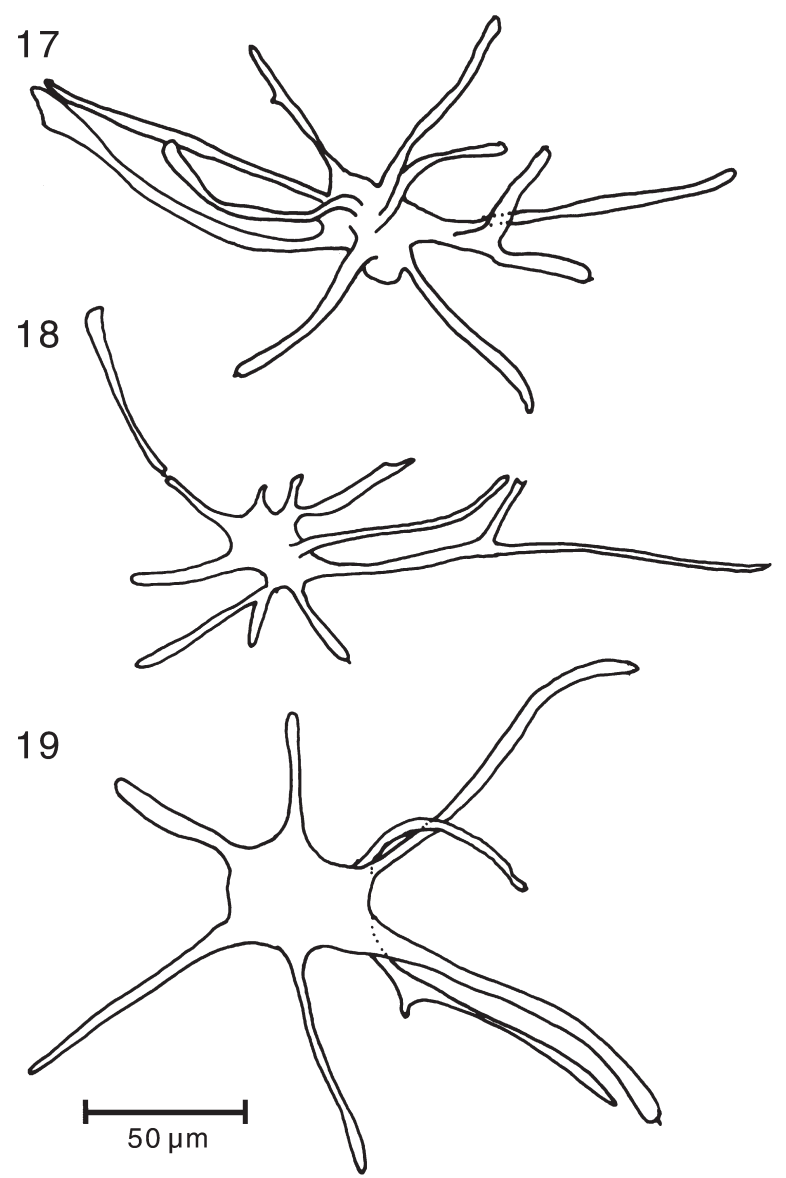

Figs 17-19. Kallymenia crassiuscula. Ganglionic cells. 
base. The specimens are female, and the cystocarps are abundantly scattered over almost the entire blade surface except for the proximal $2-3 \mathrm{~cm}$. Blade thickness measured 390-550 $\mu \mathrm{m}$, whereas cortical thickness measured only 65-80 $\mu \mathrm{m}$. Ganglionic, or stellate, cells (Figs 17-19) are present in the medulla, with conspicuous radiating processes $80-130 \mu \mathrm{m}$ in length.

Two other species of Kallymenia, Kallymenia agardhii R. E. Norris and Kallymenia schizophylla J. Agardh, can be considered. These species, both southern African endemics, have noticeably greater thicknesses (up to $1.2 \mathrm{~mm}$ in the former and to $1.0 \mathrm{~mm}$ in the latter). Special ganglionic cells in the medulla are not conspicuous in K. agardhii, and blade margins are coarsely dentate (Stegenga et al. 1997). Ganglionic cells are present in the medulla of $K$. schizophylla, and there is a negligible stipe, but blades in this species are larger (to $45 \mathrm{~cm}$ long), very deeply lobed, or split into cuneate segments, and asymmetrically curved (Norris 1964; Stegenga et al. 1997), thus different from blades of K. crassiuscula.

\section{Ceramiales: Rhodomelaceae. Chondria} crassicaulis Harvey 1860: p. 330 (Fig. 8)

Specimens examined grew at Paradise Bay, Dhofar $\left(16^{\circ} 57.07^{\prime} \mathrm{N}, 54^{\circ} 48.99^{\prime} \mathrm{E}\right)$ : 26.ix.1999, leg. Glenn Richards 26999-01-02; $11 \mathrm{~m}$ depth, on rock.

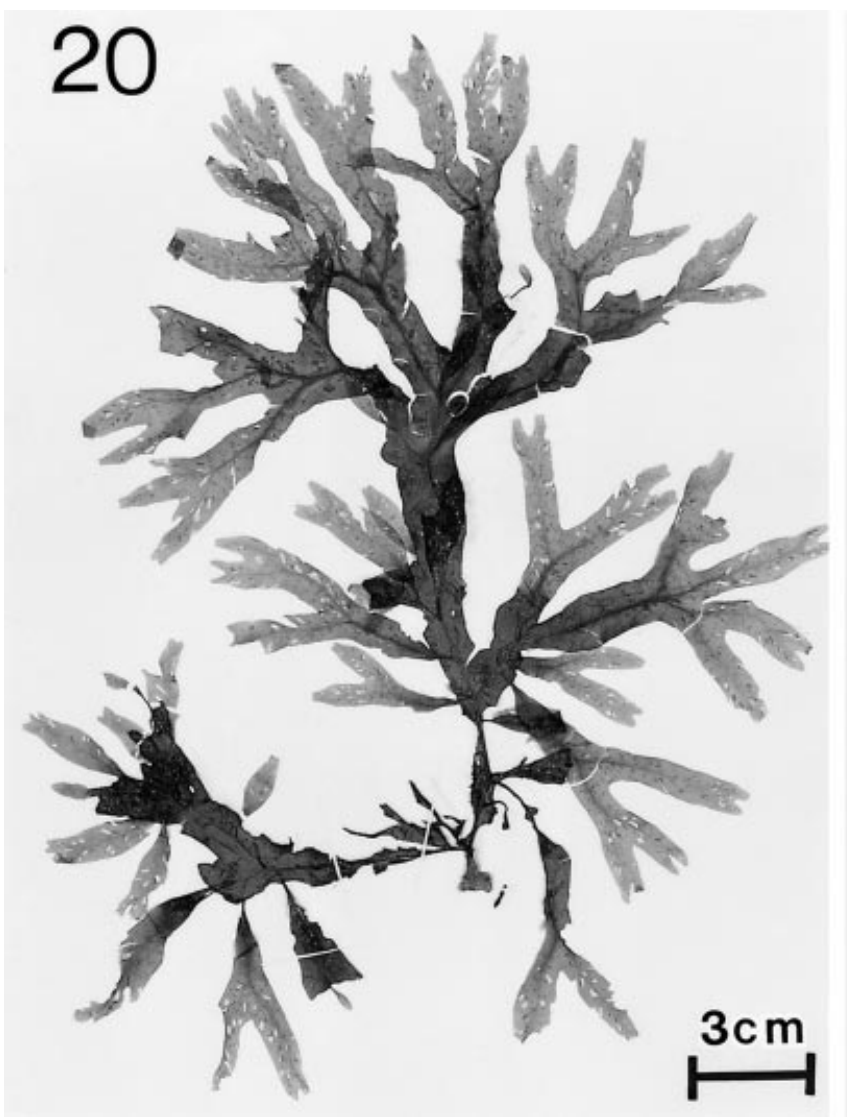

Since its description by Harvey (1860) from Shimoda and Hakodate, northern Japan, Chondria crassicaulis has been figured by various authors, including Holmes (1896; pl. 8, figs 4a-c) and Okamura (1907a; pl. 3, figs 1-15). Holmes (1896) described the main axes to be stout and succulent. He also added a query to its placement within Chondria, expressing the opinion that it might represent a new genus. His material included spermatangial plants. Earlier, J. Agardh (1892) excluded the species from Chondria, concluding that it was related to Chrysymenia. Okamura (1903) described the small reproductive branches as having a propagative function; these same structures are present in the Omani material. Okamura (1903) was convinced of its proper assignment to the genus Chondria.

Phaeophyceae. Dictyotales: Dictyotaceae. Dictyopteris divaricata (Okamura) Okamura (1942) (Fig. 20)

Specimens examined grew on a small island east of Mirbat, Dhofar (1657.00’N, 5444.75’E): 25.ix.1999, leg. Glenn Richards 25999-02-04; at 12 m depth, on sand-covered rocks.

The Omani specimens are large plants reaching $28 \mathrm{~cm}$ in height and with blades $12-20 \mathrm{~mm}$ in width. The blades, attached by a stupose, conical base, have a

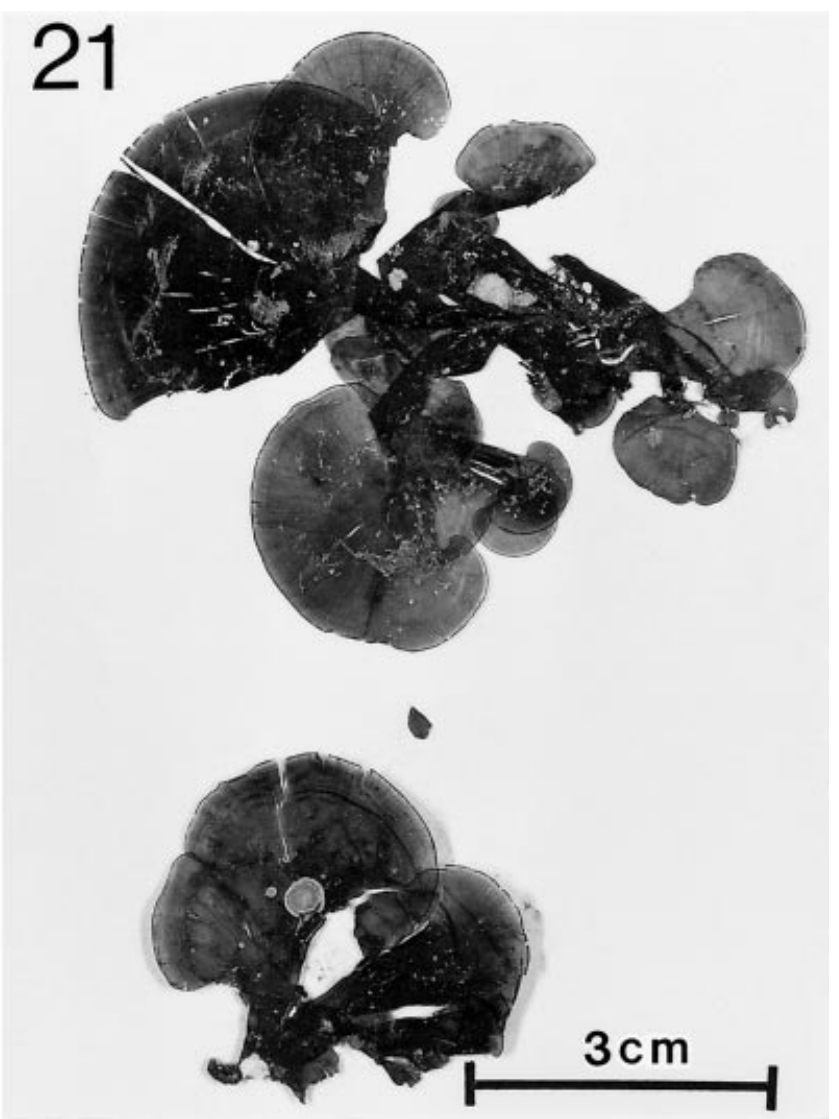

Figs 20,21. 20. Dictyopteris divaricata. Habit. 21. Distromium decumbens. Habit. 
flabellately spreading habit and are dichotomously or subpinnately divided (Fig. 20). Okamura (1907b; as Haliseris divaricata) described this species as being $15-20 \mathrm{~cm}$ tall and $10-25 \mathrm{~mm}$ broad and as having sporangial sori in minute, oval groups arranged in oblique rows on both sides of the midrib. Okamura's material was from Cape Iwai, Rikuzen, Hakodate. He later transferred it to the genus Dictyopteris (Okamura 1942). In addition to its occurrence in Japan, this species is also known from the Huanghai Sea coast of China (Tseng 1983), from Korea (Lee and Kang 1986), and eastern Russia (Perestenko 1980; Klochkova 1996). On the basis of a single drift specimen, Nizamuddin and Saifullah (1967) recognized the presence of this species from Manora, near Karachi, Pakistan. Tseng (1983) described Chinese plants as being $10-20 \mathrm{~cm}$ in height and with blade widths of $10-20 \mathrm{~mm}$.

Species of Dictyopteris previously reported from Oman include Dictyopteris hoytii W. R. Taylor (Wynne and Jupp 1998) and Dictyopteris macrocarpa (Aresch.) O. C. Schmidt (Wynne 1999b). The former species, with a type locality of Beaufort, North Carolina, USA (Taylor 1960), is distinguished by its prominent marginal and lateral veins. In the latter species, which had earlier been known only from South Africa and Mozambique (Seagrief 1980), the sori are arranged in two to four roughly longitudinal rows (Kützing 1859 as Haliseris macrocarpa; Simons 1977).

\section{Distromium decumbens (Okamura) Levring (Figs 21-23)}

Specimens examined grew in a coral garden south of island, Hallaniyat Islands $\left(17^{\circ} 28.60^{\prime} \mathrm{N}, 56^{\circ} 02.79^{\prime} \mathrm{E}\right)$ : 21.i.2000, leg. J. Hall-Spencer 210100-10-01, on rock; depth not stated.

The specimens form fan-shaped blades (Fig. 21), the individual blades being $3.5 \mathrm{~cm}$ tall and $4.0 \mathrm{~cm}$ wide. As is typical for the genus, the blades grow with many marginal initials (Fig. 22) and have a distromatic organization (Fig. 23). Although the Omani specimens were sterile, sporangia are grouped in sori for the genus.

This record represents the first report of this species from the Indian Ocean. This species was first described as Chlanidote decumbens by Okamura (1899) and was later depicted by Okamura in his Icones (1907c, 1932) under the name Chlanidote repens Okamura. Levring (1940) established the genus Distromium with the type species Distromium skottsbergii Levring from the Juan Fernandez Islands of Chile. At that time Levring transferred Okamura's $C$. decumbens to his new genus as the only other species. Three additional species were later described, Distromium flabellatum and Distromium multifidum from southern Australia (Womersley 1967, 1987) and Distromium didymothrix from Lord Howe Island, eastern Australia (Allender and Kraft 1983).

Chlorophyceae. Cladophorales:

Cladophoraceae. Cladophora ohkuboana

Holmes 1896: p. 249, pl. 10, fig. 1 (Figs 24, 25)

Specimens examined grew north-east of Sadh Bay, Dhofar $\left(17^{\circ} 02.62^{\prime} \mathrm{N}, 5^{\circ} 04.83^{\prime} \mathrm{E}\right): 29 . i x .1999$, leg. Emma Dodsworth 29999-05-02. Also, western side of Wadi Zead (Hoon's Bay), $20 \mathrm{~km}$ east of Mirbat, Dhofar: 21.x.1983, leg. TMRU; $17 \mathrm{~m}$ depth in Ecklonia forest. Mirbat, Dhofar: 21.ix.1983, leg. TMRU. Hallaniyat Islands, south-east bay on runway: 22.x.1983, leg. TMRU.

The Omani specimens are robust, the largest reaching a height of $35 \mathrm{~cm}$ (Fig. 25), with large, thick cells and a non-dense, branching habit. Holmes (1896) described this species from Enoshima, Japan. Okamura (1935), Sakai (1964) and Chihara (1970) have provided accounts of its morphology, including figures. The Omani material agrees with these accounts in having a 'vigorous, bushy, but not dense' habit and in having a primary holdfast consisting of a fibrous disc. Branching, which is dichotomous or occasionally trichotomous, is common in the proximal portions, occurring at intervals of from one to three cells (Fig. 24). Distal portions, however, are seldom branched, resulting in a flagelliform habit for the thalli. The length of cells is $1-3 \mathrm{~mm}$

22
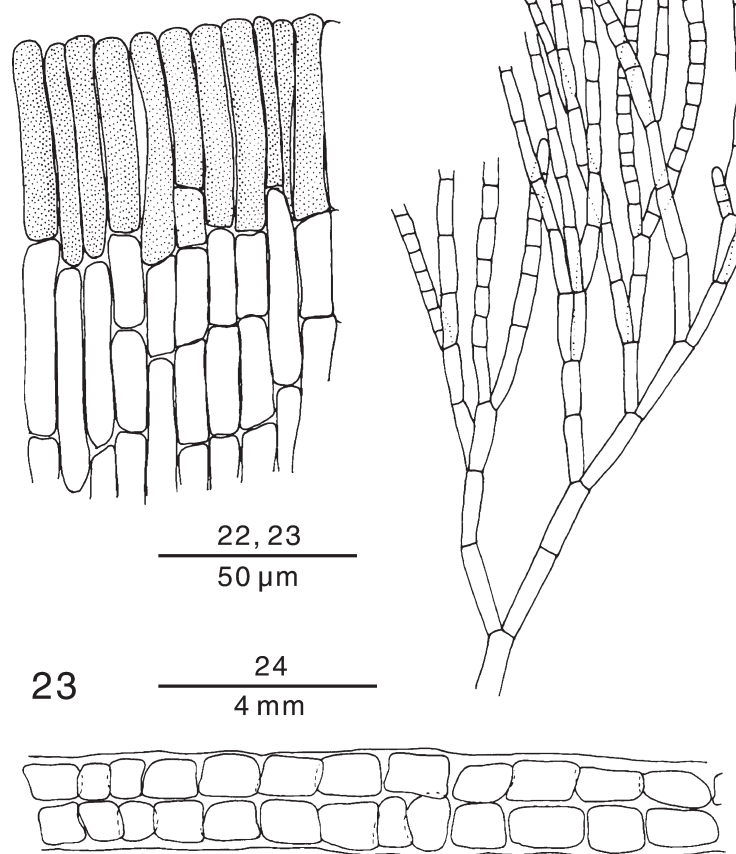

Figs 22-24. 22,23. Distromium decumbens. 22. Growing edge of thallus with many elongate initials. 23. Transverse section of thallus showing distromatic structure. 24. Cladophora ohkuboana. Branching pattern in proximal portion of thallus. 


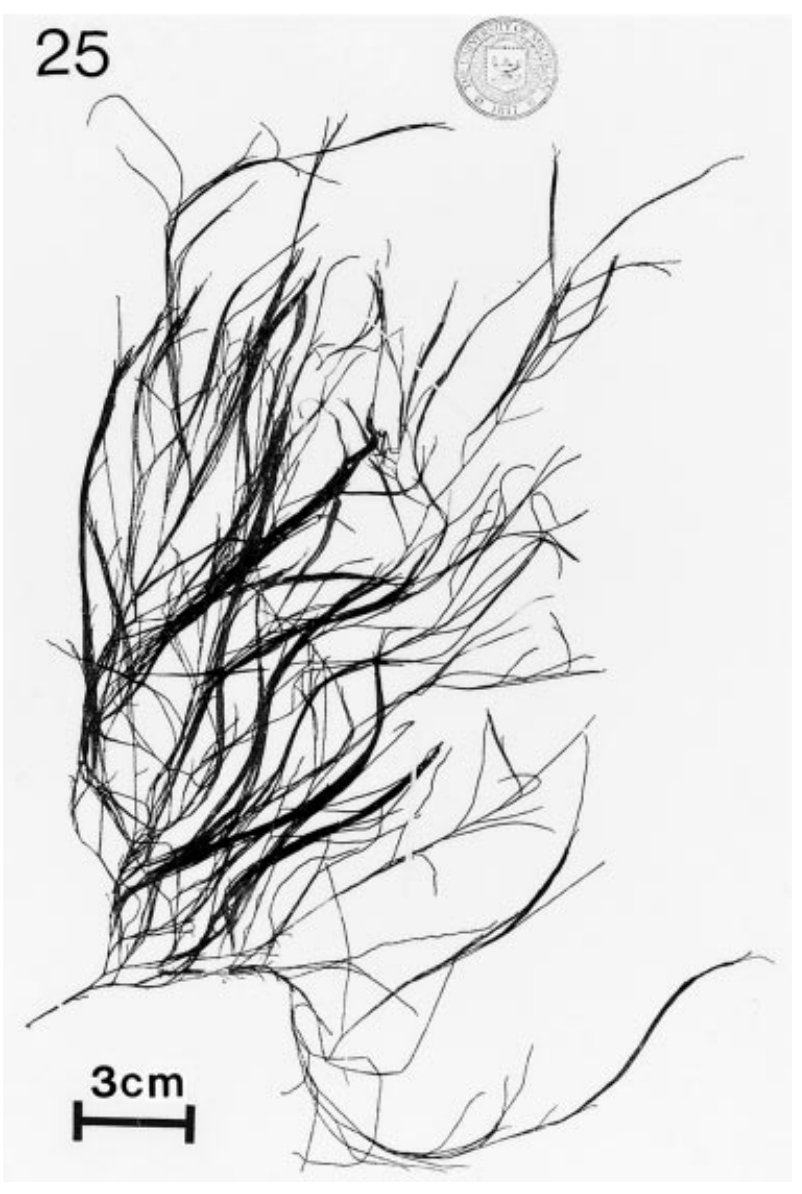

Fig. 25. Cladophora ohkuboana. Habit.

in the more distal regions and $4-8 \mathrm{~mm}$ in the more proximal regions. Okamura (1935) reported that cells reach $10-13 \mathrm{~mm}$ in the basal regions. The other species of Cladophora in the Japanese flora with axis diameters of nearly $1 \mathrm{~mm}$ are Cladophora wrightiana Harv. and Cladophora japonica Yamada. This is the thickest of those species (Sakai 1964), and it can be further distinguished from Cladophora wrightiana in lacking the basal annular rings and lacking adventitious rhizoids. It is separable from Cladophora japonica by its disc-shaped, fibrous holdfast and by its much less densely branched habit than in Cladophora japonica.

Previously, Cladophora ohkuboana was known only from Japan (Yoshida et al. 1995) and the Fujian Province of China (Tseng 1983).

\section{DISCUSSION}

Recent collections of benthic marine algae from the Sultanate of Oman have increased our understanding of the flora of this region and its affinities with other marine provinces. Barratt et al. (1986) called attention to the presence of well-developed kelp bed communities along the northern Arabian Sea coast, consisting primarily of Ecklonia radiata (C. Agardh) J. Agardh along with Nizamuddinia zanardinii (Schiffner) P. C. Silva and several species of Sargassum. This unexpected occurrence of kelp communities in the Dhofar region of southern Oman despite its tropical/subtropical latitude is a result of the upwelling from the seasonal monsoon (Currie et al. 1973; Lüning 1990). The seasonal monsoon begins in May-June, developing as a strong wind from the south-west, with winds more or less parallel to the Somali and Arabian coasts. The peak of activity occurs in July-August, fading in SeptemberOctober. According to Currie et al. (1973) the most significant feature of the south Arabian upwelling is the breadth of the upwelling zone, resulting in water being supplied from much greater depths than is usual in other coastal upwelling systems. Winds during the summertime monsoon blow surface water away from the Arabian shoreline, and this water is replaced by nutrient-rich water from a deep, northward flow (Sheppard et al. 1992). In addition to elevated nutrient levels and relatively colder water temperatures, the Dhofar coastline is also affected by increased wave action (Savidge et al. 1990). Water temperatures along the Dhofar coast dropped to less than $20^{\circ} \mathrm{C}$ during the south-west monsoon. The adjacent coast of Yemen experiences a similarly enriched marine algal flora at this time (Ormond and Banaimoon 1994) as does the Socotra Archipelago off Somalia (Kemp 1998). A richly diverse Omani flora with connections to the marine floras of South Africa (Wynne 1999b) and other remote areas is becoming evident (Wynne and Jupp 1998). This report of eight species of algae previously known only from eastern Asian waters and representing first reports for the entire Indian Ocean reinforces the observation made by Børgesen (1934) of an interesting affinity between the benthic algal floras of Japan and the northern Arabian Sea. In addition, several new taxa of apparently endemic elements have been described (Nizamuddin and Campbell 1995; Wynne 1998; 1999a). In his treatment of the biogeography of South African red algae, Hommersand (1986) noted floristic affinities between South Africa and warm-temperate Japan. He speculated that some of these taxa may have had their origins in the Tethyan Sea and radiated species in two directions. It would seem that common elements in the flora of the northern Arabian Sea (shared with South Africa and Japan) point to a more complicated picture of disjunct distributions. It is anticipated that further studies will lead to the appreciation of an even greater species richness in reference to the benthic marine algal flora, with a mixture of tropical, subtropical and warm temperate components.

\section{ACKNOWLEDGEMENTS}

The two collections of Cladophora ohkuboana cited in this paper were made in 1983 by personnel of the former Tropical Marine Research Unit of the University 
of York, UK. The more recent field work in Oman was part of the Algal Biodiversity Project of Oman (1999-2002), funded by the British Government's Darwin Initiative grant. The project was managed by Hunting Technical Services Development Ltd, UK, working with the Natural History Museum of Muscat, Oman, and supported by the Natural History Museum of London and the University of Michigan. I wish to thank Emma Dodsworth and Lynne Barratt of HTS for providing me with the collections used in this project. David Bay of the Department of Biology, University of Michigan, USA, kindly took the photographs.

\section{REFERENCES}

Afaq-Husain, S. and Shameel, M. 1991. The structure and reproduction of a new species Helminthocladia nizamuddinii (Nemaliales - Rhodophyta) from the coast of Pakistan. Bot. Mar. 34: 81-9.

Agardh, J. G. 1892. Analecta algologica. Acta Soc. Physiographicae Lundensis 28: 1-182, 3 pls.

Allender, B. M. and Kraft, G. T. 1983. The marine algae of Lord Howe Island (New South Wales): the Dictyotales and Cutleriales (Phaeophyta). Brunonia 6: 73-130.

Barratt, L., Ormond, R. F. G. and Wrathall, T. J. 1986. Ecological studies of southern Oman kelp communities. Part 1. Ecology and productivity of the sublittoral algae Ecklona radiata and Sargassopsis zanardinii. Tropical Marine Research Unit, University of York and Council for Conservation of the Environment and Water Resources, Muscat. $x i i+109+i v p p$.

Børgesen, F. 1934. Some marine algae from the northern part of the Arabian Sea with remarks on their geographical distribution. Kongelige Danske Videnskabernes Selskab. Biologiske Meddelelser 11: 72 pp., 2 pls.

Chiang, Y.-M. 1997. Species of Hypnea Lamouroux (Gigartinales, Rhodophyta) from Taiwan. In Abbott, I. A. (Ed.) Taxonomy of Economic Seaweeds with Reference to some Pacific Species 6. California Sea Grant College System, University of California, La Jolla, pp. 163-77.

Chihara, M. 1970. Common Seaweeds of Japan in Color. Hoikusha Publishing Co, Ltd., Osaka, xviii + 173 pp.

Chihara, M. 1975. [Marine Algae: Illustrated Compendium for Study by Middle and High School Students.] Gakken Co., Ltd., Tokyo, 290 pp. (in Japanese)

Currie, R. I., Fisher, A. E. and Hargreaves. P. N. 1973. Arabian Sea upwelling. In Zeitzschel, B. and Gerlach, S. A. (Eds) The Biology of the Indian Ocean. Ecological Studies 3. Springer-Verlag, New York, pp. 37-52.

Dawson, E. Y. 1944. The marine algae of the Gulf of California. Allan Hancock Pac. Exped. 3: 189-454.

Dawson, E. Y. 1953. Marine red algae of Pacific Mexico, Part I: Bangiales to Corallinaceae subf. Corallinoideae. Allan Hancock Pac. Exped. 17: 1-240, 33 pls.

Dawson, E. Y. 1959. Marine algae from the 1958 Cruise of the Stella Polaris in the Gulf of California. Los Angeles County Museum Contr. Sci. 27: 1-39.
Harvey, W. H. 1860. Characters of new algae, chiefly from Japan and adjacent regions, collected by Charles Wright in the North Pacific Exploring Expedition under Captain John Rodgers. Proc. Amer. Acad. Arts Sci. 4: 327-35.

Hayee-Memon, A. and Shameel, M. 1996. A taxonomic study of some red algae commonly growing on the coast of Karachi. Pak. J. Mar. Sci. 5: 113-37.

Holmes, E. M. 1896. New marine algae from Japan. J. Linn. Soc. Bot. 31: 248-60, pls. 7-12.

Hommersand, M. H. 1986. The biogeography of the South African marine red algae: a model. Bot. Mar. 29: 257-70.

Kemp, J. M. 1998. The occurrence of Nizamuddinia zanardinii (Schiffner) P. C. Silva (Phaeophyta: Fucales) at the Socotra Archipelago. Bot. Mar. 41: 345-8.

Klochkova, N. G. 1996. [The marine algae of Tatars Gulf (Japan Sea) and special features of its formation.] Russian Academy of Sciences, Vladivostok. $288+3$ pp. (In Russian)

Kützing, F. T. 1859. Tabulae Phycologicae oder Abbildungen der Tange. Vol IX. viii + 42 pp., 100 pls. Nordhausen.

Lee, I. K. and Kang, J. W. 1986. A check list of marine algae in Korea. Korean J. Phycol. 1: 311-25.

Lee, R. K. S. 1963. The structure and reproduction of Dudresnaya hawaiiensis sp. nov. (Rhodophyta). Am. J. Bot. 50: 315-9.

Lemoine, Mme P. 1929. Les Corallinacées de l'Archipel des Galapagos et Golfe de Panama. Arch. Mus. Hist. Nat. (Paris), Ser. 6, 4: 37-86, 4 pls.

Levring, T. 1940. Die Phaeophyceengattungen Chlanidophora, Distromium und Syringoderma. Kungl. Fysiografiska Sällskapets I Lund Förhandlingar 10, 11 pp.

Lüning, K. 1990. Seaweeds. Their Environment, Biogeography, and Ecophysiology. (English language edition by C. Yarish and H. Kirkman.) John Wiley \& Sons, New York, xiii + 527 pp.

Nizamuddin, M. 1997. A new species of the genus Codium Stackh., from the coast of Pakistan. Pak. J. Bot. 29: 179-84.

Nizamuddin, M. 1999. Codium saifullahii Nizam., sp. nov. from the coast of Pakistan. Pak. J. Bot. 31: 215-8.

Nizamuddin, M. and A. C. Campbell. 1995. Glossophorella, a new genus of the family Dictyotaceae (DictyotalesPhaeophyta) and its ecology from the coast of the Sultanate of Oman. Pak. J. Bot. 27: 257-62.

Nizamuddin, M. and S. M. Saifullah. 1967. Studies on marine algae of Karachi: Dictyopteris Lamouroux. Bot. Mar. 10: 169-79.

Norris, J. N. and Johansen, H. W. 1981. Articulated coralline algae of the Gulf of California, Mexico, I: Amphiroa Lamouroux. Smithsonian Contr. Mar. Sci. 9: iii + 29 pp.

Norris, R. E. 1964. The morphology and taxonomy of South African Kallymeniaceae. Bot. Marina 7: 90-129.

Okamura, K. 1899. Contribution to the knowledge of the marine algae of Japan III. Bot. Mag. Tokyo 12: 1-17, 1 pl. (repaginated reprint)

Okamura, K. 1903. On the vegetative multiplication of Chondria crassicaulis and its systematic position. Bot. Mag. Tokyo 17: 1-5. 
Okamura, K. 1907a. Icones of Japanese Algae 1 (1): 12-16 (pl. 3). Privately published, Tokyo.

Okamura, K. 1907b. Icones of Japanese Algae 1 (3): 57-9 (pl. 13). Privately published, Tokyo.

Okamura, K. 1907c. Icones of Japanese Algae 1 (5): 112-16 (pl. 24). Privately published, Tokyo.

Okamura, K. 1908. Icones of Japanese Algae 1 (9): 209-17 (pls 41,42). Privately published, Tokyo.

Okamura, K. 1909. Icones of Japanese Algae 2 (2): 35-8 (pls 59,60). Privately published, Tokyo.

Okamura, K. 1932. Icones of Japanese Algae 6 (6): 55-6 (pl. 279). Privately published, Tokyo.

Okamura, K. 1934. Icones of Japanese Algae 7 (3): 21 (pl. 313). Privately published, Tokyo.

Okamura, K. 1935. Icones of Japanese Algae 7 (5): 47 (pl. 325). Privately published, Tokyo.

Okamura, K. 1942. Icones of Japanese Algae 7 (10): 88. Privately published, Tokyo.

Ormond, R. F. G. and Banaimoon, S. 1994. Ecology of intertidal macroalgal assemblages on the Hadramout coast of southern Yemen, an area of seasonal upwelling. Mar. Ecol. Prog. Ser. 105: 105-20.

Papenfuss, G. F. 1947. New marine algae from South Africa. I. Univ. Calif. Publs. Bot. 23: 1-16.

Perestenko, L. P. 1980. [Marine Algae of Peter the Great Bay.] Nauka, Leningrad. (In Russian)

Robins, P. A. and Kraft, G. T. 1985. Morphology of the type and Australian species of Dudresnaya (Dumontiaceae, Rhodophyta). Phycologia 24: 1-34.

Sakai, Y. 1964. The species of Cladophora from Japan and its vicinity. Sci. Pap. Inst. Algol. Res., Fac. Sci., Hokkaido Imp. Univ. 5: 104, pls I-XVII, errata.

Savidge, G., Lennon, H. J. and Matthews, A. D. 1990. A shore based survey of upwelling along the coast of Dhofar region, southern Oman. Continental Shelf Res. 10: 259-75.

Seagrief, S. C. 1980. Seaweeds of Maputaland. In Bruton, M. N. and Cooper, K. H. (Eds) Studies on the Ecology of Maputaland. Rhodes University and the Natal Branch of the Wildlife Society of Southern Africa, Durban, pp. 18-41.

Segawa, S. 1940. Systematic anatomy of the articulated corallines. II. Amphiroa misakiensis Yendo. J. Jap. Bot. 16: 488-94.

Segawa, S. 1960. Coloured Illustrations of the Seaweeds of Japan. Revised edition. Hoikusha, Osaka, Japan. xviii + $175 \mathrm{pp}$.

Shameel, M. 1999. Melanothamnus afaqhusainii, a new red alga from the coast of Karachi. Pak. J. Bot. 31: 211-4.

Shameel, M., Afaq-Husain, S. and Shahid-Husain, S. 1989. Addition to the knowledge of seaweeds from the coast of Lasbela, Pakistan. Bot. Mar. 32: 177-80.

Shameel, M., Aisha, K. and Khan, S. H. 1996. A preliminary survey of seaweeds from the coast of Makran, Pakistan. Bot. Mar. 39: 223-30.

Shameel, M. and Tanaka, J. 1992. A preliminary check-list of marine algae from the coast and inshore waters of Pakistan. In Nakaike, T. and Malik, S. (Eds) Cryptogamic
Flora of Pakistan, Vol. 1. National Science Museum, Tokyo, pp. 1-64.

Sheppard, C. R. C., Price, A. and Roberts, C. 1992. Marine Ecology of the Arabian Region. Patterns and Processes in Extreme Tropical Environments. Academic Press, London, $359 \mathrm{pp}$.

Silva, P. C., Meñez, E. G. and Moe, R. L. 1987. Catalog of the benthic marine algae of the Philippines. Smithsonian Contr. Mar. Sci. 27: 179 pp.

Simons, R. H. 1977. ['1976'] Seaweeds of southern Africa: guidelines for their study and identification. Fish. Bull. S. Afr. 7: 1-113.

Sohrabipour, J. and Rabii, R. 1999. A list of marine algae of seashores of Persian Gulf and Oman sea in the Hormozgan province. Iranian J. Bot. 8: 131-62.

Stegenga, H., Bolton, J. J. and Anderson, R. J. 1997. Seaweeds of the South African west coast. Contr. Bolus Herbarium 18: $655 \mathrm{pp}$.

Tanaka, T. 1941. The genus Hypnea from Japan. Sci. Papers Inst. Algol. Res., Fac. Sci., Hokkaido Imp. Univ 2: 227-50. pls LII-LIV.

Taylor, W. R. 1945. Pacific marine algae of the Allan Hancock Expeditions to the Galapagos Islands. Allan Hancock Pac. Exped. 12: iv +528 pp., 100 pls.

Taylor, W. R. 1960. Marine Algae of the Eastern Tropical and Subtropical Coasts of the Americas. University of Michigan Press, Ann Arbor, xi +870 pp.

Tseng, C. K., ed. 1983. Common Seaweeds of China. English edition. Science Press, Beijing, $x+316 p p$.

Womersley, H. B. S. 1967. A critical survey of the marine algae of southern Australia. II. Phaeophyta. Aust. J. Bot. 15: 189-270.

Womersley, H. B. S. 1987. The marine benthic flora of southern Australia Part II. Handbook of the Flora and Fauna of South Australia. Southern Australian Government Printing Division, Adelaide, $484 \mathrm{pp}$.

Wynne, M. J. 1998. Champia gigantea and Lomentaria strumosa (Rhodymeniales): two new red algae from the Sultanate of Oman. Bot. Mar. 41: 571-80.

Wynne, M. J. 1999a. Pseudogrinnellia barrattiae gen. et sp. nov., a new member of the red algal family Delesseriaceae from the Sultanate of Oman. Bot. Mar. 42: 37-42.

Wynne, M. J. 1999b. New records of benthic marine algae from the Sultanate of Oman. Contr. Univ. Mich. Herb. 22: 189-208.

Wynne, M. J. and Jupp, B. P. 1998. The benthic marine algal flora of the Sultanate of Oman: new records. Bot. Mar. 41: 7-14.

Xia B. and Wang Y. 1997. Some species of Hypnea (Gigartinales, Rhodophyta) from China. In Abbott, I. A. (Ed.) Taxonomy of Economic Seaweeds with reference to some Pacific species. Vol. 6. California Sea Grant College System, University of California, La Jolla, pp. 193-206.

Yamagishi, Y. and Masuda M. 1997. Species of Hypnea from Japan. In Abbott, I. A. (Ed) Taxonomy of Economic Seaweeds with Reference to Some Pacific Species. 
Vol 6. California Sea Grant College System, University of California, La Jolla, pp. 135-62.

Yendo, K. 1902. Corallinae verae Japonicae. Journal of the College of Science, Imperial University, Tokyo, Japan 16: $1-36+[2], 7$ pls.
Yoshida, T. 1998. Marine Algae of Japan. Uchida Rokakuho Publishing Co, Ltd., Tokyo, 1222 pp. (In Japanese)

Yoshida, T., Yoshinaga, K. and Nakajima, Y. 1995. Check list of marine algae of Japan (revised in 1995). Jpn. J. Phycol. 43: 115-71. 